present series who developed pulmonary emboli deep vein thrombosis was apparently confined to the calf; in the patient who died this was confirmed at necropsy. These findings agree with those of Murray et al. (1970); they found evidence of pulmonary embolism after myocardial infarction in 4 out of 12 patients with thrombosis below the knee, but in none of those with normal radioactivity counts. It is accepted that the fibrinogen test cannot detect thrombi above mid-thigh level with any degree of accuracy (Flanc et al., 1968; Negus and Evans, 1971), so some of these patients may also have had undetected iliofemoral thrombosis. Notwithstanding this, the only patients in either series who had pulmonary emboli also had fibrinogendetectable thrombosis of the calf vein. These thrombi, therefore, seem worth preventing. In the present trial heparin, given by continuous intravenous infusion, seemed to be capable of doing this effectively.

The decision to give this drug routinely after myocardial infarction is still a difficult one, which would be easier to make if a safer regimen could be shown to be effective. Sharnoff and DeBlasio (1970) and Williams (1971) reported favourably on low-dose subcutaneous heparin prophylaxis in surgical cases. The possibility of using such a regimen after myocardial infarction is being explored.

We should like to thank the physicians of the Westminster Hospital Group for allowing us to study patients under their care; and Dr. Ian Sutherland for statistical advice. A.J.H. is in receipt of the H.A.M. Thompson Fellowship from the Royal College of Physicians of London. We are grateful to the British
Heart Foundation, the Peel Medical Research Trust, and the Board of Governors of Westminster Hospital for financial help.

\section{References}

Browse, N. L., et al. (1971). British Medical fournal, 4, 325.

Documenta Geigy (1970). Scientific Tables, p. 711. Basle, Geigy

Flanc, C., Kakkar, V. V., and Clarke, M. B. (1968). British fournal of Surgery, 55, 742 .

Flute, P. T. (1969). British Medical fournal, 4, 678.

Handley, A. J. (1967). British Medical fournal, $2,482$.

Handley, A. J. (1970a). Lancet, 2, 313.

Handley, A. J. (1970b). British Medical fournal, 1, 234

Johnson, D. C., and Reeve, T. S. (1969). Australian and New Zealand Fournal of Surgery, 39, 209.

Kakkar, V. V. (1971). British fournal of Hospital Medicine, 6, 741.

Kakkar, V. V., Howe, C. T., Flanc, C., and Clarke, M. B. (1969). Lancet,

2, 230. ., Nicolaides, A. N., Renney, J. T. G., Friend, J. R., and Clarke, M. B. (1970). Lancet, 1, 540 .

Lambie, J. M., et al. (1970). British Medical fournal, 2, 142.

Martyn, D. T., and Janes, J. M. (1971). Mayo Clinic Proceedings, $46,347$.

Maurer, B. J., Wray, R., and Shillingford, J. P. (1971). Lancet, 2, 1385.

Medical Research Council, (1969). British Medical fournal, 1, 335

Murray, T. S., Lorimer, A. R., Cox, F. C., and Lawrie, T. D. V. (1970). Lancet, 2, 792.

Negus, D., and Evans, D. S. (1971). Lancet, 2, 763.

Negus, D., Pinto, D. J., Le Quesne, L. P., Brown, N., and Chapman, M. (1968). British fournal of Surgery, 55, 835.

Nicolaides, A. N., et al. (1971). British Medical fournal, 1, 432.

Norris, R. M., Brandt, P. W. T., Caughey, D. E., Lee, A. J., and Scott, P. J. (1969). Lancet, 1, 274.

Pai, B. Y., and Negus, D. (1971). Lancet, 2, 1098.

Peel, A. F., Semple, T., Wong, I., Lancaster, M. M., and Dall, J. L. G. (1962). British Heart fournal, 24, 745.

Sharnoff, J. G., and DeBlasio, G. (1970). Lancet, 2, 1006.

Wharnoff, J. G., and DeBlasio, G. (1970).

Williams, H. T. (1971). Lancet, 2, 950 . London, Eyre and Spottiswoode.

\title{
Splenic Atrophy in Dermatitis Herpetiformis
}

\author{
J. E. PETTIT, A. V. HOFFBRAND, P. P. SEAH, LIONEL FRY
}

British Medical fournal, 1972, 2, 438-440

\section{Summary}

Twenty-four patients with dermatitis herpetiformis were investigated for splenic atrophy by splenic scan and clearance of ${ }^{51} \mathrm{Cr}$-labelled heat-damaged red blood cells. Eight of them had definite splenic atrophy. The average splenic cross-sectional area of the remaining 16 with normal clearance times was substantially smaller than normal, suggesting some degree of splenic atrophy. No relationship of splenic hypofunction to intestinal biopsy findings, folate status, reticulin antibody, or treatment with a gluten-free diet or dapsone was evident.

\section{Introduction}

Considerable interest has been shown in the recent finding that patients with dermatitis herpetiformis show an enteropathy similar to that of coeliac disease (Marks et al., 1966; Fraser et al., 1967; Fry et al., 1967; Brow et al., 1971). Because they found that both the skin and gut lesions improved when patients

Department of Haematology, Royal Postgraduate Medical School, London W.12

J. E. PETTIT, M.B., CH.B., M.R.C.PATH., Senior Registrar

A. V. HOFFBRAND, B.M., B.CH., M.R.C.P., D.c.P., Lecturer, Honorary Consultant

Department of Dermatology, St. Mary's Hospital, London W.2

P. P. SEAH, M.B., B.S., M.R.C.P., Research Fellow

LIONEL FRY, M.D., M.R.C.P., Consultant Physician

with dermatitis herpetiformis received a gluten-free diet, and relapsed on reintroduction of gluten, Fry et al. (1969) suggested a direct relation between the skin and small intestine in this disorder.

Seah et al. (1971a, 1971b) demonstrated the presence of reticulin antibodies in the sera of a proportion of patients with both dermatitis herpetiformis and coeliac disease. Since the spleen is the largest organized collection of lymphoreticular tissue in the body and the occurrence of splenic atrophy in coeliac disease is well established (Martin and Bell, 1965; McCarthy et al., 1966; Ferguson et al., 1970; Marsh and Stewnrt, 1970), we have investigated splenic size and function in a group of patients with dermatitis herpetiformis to further clarify the relation between dermatitis herpetiformis and coeliac disease.

\section{Patients and Methods}

Twenty-four consecutive patients attending a dermatitis herpetiformis clinic were studied (see Table). There were 14 men aged 28-75 (average 52) and 10 women aged 26-65 (average 38). At the time of these studies seven patients had their rash controlled by a gluten-free diet alone, nine were receiving a gluten-free diet, and dapsone, and eight were receiving dapsone only.

Assessment of Splenic Function.-Autologous red cells were labelled with $150 \mu \mathrm{Ci}$ of ${ }^{51} \mathrm{Cr}$ and damaged by heating for 20 minutes at $49.5^{\circ} \mathrm{C}$. Splenic function was assessed by measuring the rate of clearance of the ${ }^{51} \mathrm{Cr}$-labelled cells. After the intravenous injection of these cells, blood samples were taken at 3,10 , 20,30 , and 60 minutes, haemolysed, and radioactivity counted 
in a well-scintillation counter. The results were plotted on semi-logarithmic graph paper, taking the activity of the threeminute sample as $100 \%$. The half-time of clearance of the ${ }^{51} \mathrm{Cr}$ label from the circulation (read from the graph) was used as an index of splenic function. In control patients suffering from localized head and neck malignancy or bladder carcinoma, Marsh et al. (1966) found this time to be within the range of 10-16 minutes. Subsequent studies in our laboratory on 20 other patients who have had no evidence of splenic disease have shown half-clearance times within this range. One hour after the injection of the labelled, damaged cells the patient's splenic area was scanned with a dual-detector scanner (Picker). The cross-sectioned area of the spleen outlined on this anteroposterior scan was calculated with a planimeter.

Haematological Investigations.-Routine blood counts were measured on the day of the splenic study (Dacie and Lewis, 1968). Two peripheral blood films from each patient were stained by a May-Grünwald-Giemsa technique and examined; the presence of Howell-Jolly bodies with or without target cells and of crenated and contracted red cells was considered presumptive evidence of splenic atrophy. Serum folate levels were determined by microbiological assay with Lactobacillus case $i$ as test organism (Waters and Mollin, 1961). The normal range is 6-21 ng/ml. Red cell folate was measured as described by Hoffbrand et al. (1966). The normal range is $160-640 \mathrm{ng} / \mathrm{ml}$ packed cells.

Small-intestinal Biopsy.-Biopsy specimens were taken from the upper jejunum at the ligament of Treitz by using a special capsule (Crosby and Kugler, 1957) under radiological control. The specimen was fixed in $10 \%$ formol-saline before processing for histological examination and it was examined and photographed with a Zeiss standard Universal dissection microscope using a 3-in $(7 \cdot 5-\mathrm{cm})$ objective. Sections of the specimen were then cut and stained: (1) with haematoxylin and eosin and (2) according to the methylgreen-pyronin technique for the specific identification of plasma cells.

Reticulin Antibody.-This was detected as described by Seah et al. (1971a).

\section{Results}

Clearance of Heat-damaged Red Cells and Splenic Cross-sectional Area.-Eight of the 24 patients had prolonged half-clearance times (see Table). Three patients (Cases 1,2, and 3) who had the most prolonged half-clearance times, of greater than one hour, had no evidence of functioning splenic tissue on the scintillation scan. In the remaining five patients with abnormal clearance times, three (Cases 4, 5, and 6) had particularly small splenic cross-sectional areas of 18,13 , and $14 \mathrm{~cm}^{2}$ respectively. Of the 16 patients with normal clearance times (Cases 9-24), one (Case 14) had a splenic cross-sectional area which could be considered to be definitely smaller than normal $\left(16 \mathrm{~cm}^{2}\right)$. However, the mean area among these 16 patients was only $42.0 \mathrm{~cm}^{2}$, compared with the Larson et al. (1970) mean normal level of $52.8 \mathrm{~cm}^{2}$, and as many as 14 of the 16 patients had splenic cross-sectional areas of less than $52.8 \mathrm{~cm}^{2}$, as did Cases 7 and 8 who had slow clearance times.

Blood Film Evidence of Splenic Atrophy.-Howell-Jolly bodies were obvious in the films of 7 of the 24 patients. The amount of targetting, contraction, and crenation of red cells in these patients was variable, and minor degrees of these latter red cell changes were observed in a proportion of the patients in whom no Howell-Jolly bodies were observed. All the patients with Howell-Jolly bodies had longer than normal half-clearance times, but one (Case 7), who had a slow half-clearance time (19 minutes), showed no blood film evidence of splenic atrophy (see Chart).

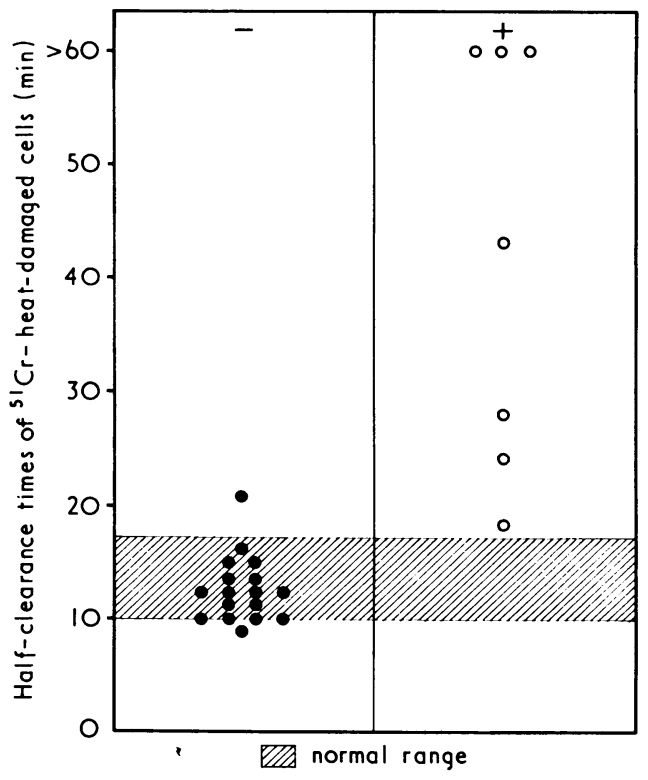

Comparing the half-clearance time of ${ }^{51} \mathrm{Cr}$ heatdamaged red cells with the peripheral blood film in the 24 patients with dermatitis herpetiformis. Closed circles = no Howell-Jolly bodies; open circles = Howell-Jolly bodies present.

Splenic Studies in Dermatitis Herpetiformis

\begin{tabular}{|c|c|c|c|c|c|c|c|c|c|c|}
\hline \multirow{2}{*}{$\begin{array}{l}\text { Case } \\
\text { No. }\end{array}$} & \multirow{2}{*}{$\begin{array}{c}\text { Sex and } \\
\text { Age }\end{array}$} & \multirow{2}{*}{$\begin{array}{c}\text { Half- } \\
\text { Clearance } \\
\text { of } \\
\text { Damaged } \\
\text { Cells } \\
\text { (Min) }\end{array}$} & \multirow{2}{*}{$\begin{array}{l}\text { Scan } \\
\text { Size } \\
\left(\mathrm{cm}^{2}\right)\end{array}$} & \multirow{2}{*}{$\begin{array}{c}\text { Blood } \\
\text { Film } \\
\text { Evidence } \\
\text { of } \\
\text { Splenic } \\
\text { Atrophy }\end{array}$} & \multicolumn{3}{|c|}{ Gut Biopsy } & \multirow{2}{*}{ Therapy } & \multirow{2}{*}{$\begin{array}{l}\text { Folate Level in } \\
\text { Serum/R.B.C. } \\
(\mathbf{n g} / \mathrm{ml})\end{array}$} & \multirow{2}{*}{$\begin{array}{l}\text { Reticulin } \\
\text { Antibody }\end{array}$} \\
\hline & & & & & Macroscopic & Epithelium & $\begin{array}{l}\text { Cellular } \\
\text { Infiltrate } †\end{array}$ & & & \\
\hline $\begin{array}{l}1 \\
2 \\
3 \\
4 \\
5 \\
6 \\
7 \\
8 \\
9 \\
10 \\
11 \\
12 \\
13 \\
14 \\
15 \\
16 \\
17 \\
18 \\
19 \\
20 \\
21 \\
22 \\
23 \\
24\end{array}$ & $\begin{array}{l}\text { F. } 37 \\
\text { M. } 60 \\
\text { F. } 35 \\
\text { M. } 71 \\
\text { M. } 54 \\
\text { M. } 74 \\
\text { F. } 25 \\
\text { F. } 48 \\
\text { F. } 29 \\
\text { F. } 65 \\
\text { F. } 52 \\
\text { M. } 68 \\
\text { M. } 64 \\
\text { F. } 38 \\
\text { F. } 32 \\
\text { M. } 49 \\
\text { M. } 26 \\
\text { M. } 55 \\
\text { M. } 33 \\
\text { M. } 34 \\
\text { M. } 37 \\
\text { F. } 30 \\
\text { M. } 36 \\
\text { M. } 56\end{array}$ & $\begin{array}{l}90 \cdot 0 \\
85.0 \\
75.0 \\
42.0 \\
27.0 \\
24 \cdot 0 \\
19.0 \\
17.5 \\
15.5 \\
14.5 \\
14.0 \\
13.0 \\
13.0 \\
12.0 \\
12.0 \\
12.0 \\
12.0 \\
11.0 \\
11.0 \\
10.0 \\
10.0 \\
10.0 \\
10.0 \\
9.5\end{array}$ & $\begin{array}{l}\text { Nil } \\
\text { Nil } \\
\text { Nil } \\
18 \\
13 \\
14 \\
30 \\
40 \\
39 \\
45 \\
35 \\
36 \\
42 \\
16 \\
46 \\
36 \\
58 \\
50 \\
51 \\
58 \\
35 \\
40 \\
43 \\
42\end{array}$ & $\begin{array}{l}+ \\
+ \\
+ \\
+ \\
\pm \\
\pm \\
\pm \\
= \\
= \\
= \\
= \\
= \\
= \\
= \\
=\end{array}$ & $\begin{array}{l}\text { Flat } \\
\text { Convoluted } \\
\text { Flat } \\
\text { Flat } \\
\text { Convoluted } \\
\text { Convoluted } \\
\text { Fingers + leaves } \\
\text { Flat } \\
\text { Flat } \\
\text { Flat } \\
\text { Fingers + leaves } \\
\text { Leaves } \\
\text { Flat } \\
\text { Convoluted } \\
\text { Convoluted } \\
\text { Leaves } \\
\text { Leaves } \\
\text { Fingers + Leaves } \\
\text { Flat } \\
\text { Fingers + leaves } \\
\text { Flat + convoluted } \\
\text { Flat } \\
\text { Fingers + leaves } \\
\text { Leaves + convoluted }\end{array}$ & $\begin{array}{c}\text { Cuboidal } \\
\text { Columnar + cuboidal } \\
\text { Columnar +cuboidal } \\
\text { Cuboidal } \\
\text { Columnar } \\
\text { Columnar } \\
\text { Columnar } \\
\text { Cuboidal } \\
\text { Cuboidal } \\
\text { Cuboidal } \\
\text { Columnar } \\
\text { Cuboidal } \\
\text { Cuboidal } \\
\text { Columnar } \\
\text { Columnar } \\
\text { Columnar } \\
\text { Cuboidal } \\
\text { Columnar } \\
\text { Cuboidal } \\
\text { Columnar } \\
\text { Cuboidal } \\
\text { Cuboidal } \\
\text { Columnar } \\
\text { Columnar }\end{array}$ & $\begin{array}{l}+ \\
+ \\
++ \\
+ \\
+ \\
++ \\
++ \\
+ \\
+ \\
+ \\
+ \\
++ \\
+ \\
+ \\
+ \\
+ \\
+ \\
++ \\
+ \\
++ \\
++ \\
+ \\
+\end{array}$ & $\begin{array}{l}\text { G.F.D. + dapsone } \\
\text { G.F.D. } \\
\text { G.F.D. + dapsone } \\
\text { G.F.D. } \\
\text { G.F.D. } \\
\text { Dapsone } \\
\text { Dapsone } \\
\text { Dapsone } \\
\text { Dapsone } \\
\text { G.F.D. } \\
\text { Dapsone } \\
\text { G.F.D. + dapsone } \\
\text { G.F.D. + dapsone } \\
\text { Dapsone } \\
\text { Dapsone } \\
\text { Dapsone } \\
\text { G.F.D. } \\
\text { G.F.D. + dapsone } \\
\text { G.F.D. + dapsone } \\
\text { G.F.D. + dapsone } \\
\text { G.F.D. + dapsone } \\
\text { G.F.D. } \\
\text { G.F.D. } \\
\text { G.F.D. + dapsone }\end{array}$ & $\begin{array}{c}3 \cdot 0 / 76 \\
4 \cdot 8 / 225 \\
2 \cdot 0 / 186 \\
\text { Receiving folic acid } \\
2 \cdot 0 / 108 \\
2 \cdot 4 / 197 \\
7 \cdot 6 / 351 \\
\text { Receiving folic acid } \\
2 \cdot 8 / 266 \\
3 \cdot 9 / 128 \\
5 \cdot 2 / 185 \\
4 \cdot 1 / 125 \\
2 \cdot 8 / 445 \\
3 \cdot 0 / 111 \\
6 \cdot 0 / 363 \\
7 \cdot 5 / 260 \\
3 \cdot 6 / 258 \\
4 \cdot 4 / 297 \\
1 \cdot 0 / 116 \\
4 \cdot 6 / 267 \\
5 \cdot 6 / 246 \\
4 \cdot 1 / 187 \\
5 \cdot 2 / 198 \\
5 \cdot 8 / 189\end{array}$ & $\begin{array}{l} \pm \\
\pm \\
= \\
= \\
= \\
\pm \\
= \\
\pm \\
= \\
= \\
=\end{array}$ \\
\hline
\end{tabular}


Small-intestinal Biopsy Appearances; Reticulin Antibody; Patients' Diet and Folate Status.-The macroscopic appearances of the intestinal biopsy ranged from flat to normal. Histologically all the biopsies showed varying degrees of cellular infiltration. The three patients in whom no spleen could be demonstrated on the scan all showed macroscopic abnormality. However, there was no overall correlation between splenic size and morphological appearances of the small-intestinal mucosa. Likewise, there was no relation of splenic size to whether or not the patient was on a gluten-free diet, to folate status, or to the presence or absence of the reticulin antibody in the serum.

\section{Discussion}

These results show that a third of patients with dermatitis herpetiformis had unequivocal evidence of splenic atrophy, as assessed by clearance of damaged red cells, splenic scan, and blood film appearance. Moreover, the splenic scan studies suggest that most of the remaining patients had some degree of splenic atrophy.

The presence of splenic atrophy in patients with primary malabsorption syndromes has been known for some time. McCarthy et al. (1966) found evidence of lymphoreticular atrophy in 4 out of 25 patients with "idiopathic steatorrhoea." Three of these patients had extremely small spleens, while the spleen of the fourth patient was normal in size.

Radioisotope-labelled heat-damaged red cells have been widely used to measure the functional size of the spleen, and there seems to be a relation between clearance rates of the labelled cells and the reticuloendothelial function of the spleen (Marsh et al., 1966; Pettit et al., 1971). Marsh and Stewart (1970) found greater than normal clearances of heat-damaged ${ }^{\text {s1 }} \mathrm{Cr}$-labelled red cells in 14 out of 19 patients with adult coeliac disease and five of these patients showed no localization of radioisotope in the splenic area and had blood film appearances of splenic atrophy.

Fry et al. (1967) found Howell-Jolly bodies and target cells in the blood films of 2 out of 12 patients with dermatitis herpetiformis examined. The finding here of slower than normal clearances in 8 of the 24 patients clearly shows that splenic hypofunction is common in patients with dermatitis herpetiformis. Although at first sight it would seem that splenic hypofunction is somewhat less frequent in dermatitis herpetiformis than in coeliac disease, a closer inspection of the results shows that even the dermatitis herpetiformis patients with normal clearance times tended to have smaller functional splenic crosssectional areas than normals. The normal splenic cross-sctional area as determined by rectilinear scintillation scanning is not well established. Holzback et al. (1962) reported a range between 35 and $85 \mathrm{~cm}^{2}$ in a series of 23 control patients. Larson et al. (1970) studied 26 healthy adults and found a mean crosssectional area of $52.8 \mathrm{~cm}^{2}$ in the posterior rectilinear spleen scans. In the 16 dermatitis herpetiformis patients reported here who had normal clearance times the mean cross-sectional area was only $42.0 \mathrm{~cm}^{2} ; 14$ of the 16 patients had areas less than the mean normal value quoted above and a patchy distribution of isotope was evident in some cases. This, though not conclusive, strongly suggests that most of the patients, even with normal clearance, have some degree of splenic atrophy.

No overall correlation was found in this study between the size of the spleen and the severity of the small-intestinal mucosal abnormality. In addition, there was no correlation between splenic size and the control of the eruption by a gluten-free diet. These findings are similar to the previous experience of splenic atrophy in coeliac disease in which no relation was found between the presence or absence of splenic atrophy and the clinical and laboratory findings in those patients (Marsh and Stewart, 1970).

Our results are yet further evidence that patients with dermatitis herpetiformis have coeliac disease, for not only is the small-intestinal lesion similar in both disorders but a similar abnormality of the spleen is present. The explanation of the splenic atrophy in dermatitis herpetiformis and coeliac disease is obscure at the present time but it may well be a further manifestation of an abnormality of the lymphoreticular system suggested by the finding of reticulin antibody in these disorders.

We thank Dr. L. Szur and Dr. S. M. Lewis for helpful advice, Mr. J. O. Morgan for the microbiological assay results, and Misses Linda Larsen and Susan Moss for expert technical help. P.P.S. and L.F. are in receipt of grants from the M.R.C. and Wellcome Trust.

Requests for reprints should be sent to Dr. J. E. Pettit.

\section{References}

Brow, J. R., Parker, F., Weinstein, W. M., and Rubin, C. E. (1971). Gastroenterology, 60, 1355

Crosby, W. H., and Kugler, H. W. (1957). American Journal of Digestive

Diseases, 2, 236.
Dacie, J. V., and Lewis, S. M. (1968). Practical Haematology, 4th edn.

London, Churchill.
Ferguson, A., Hutton, M. Maxwell, J. D., and Murray, D. (1970). Lancet, $1,163$.

Fraser, N. G., Murray, D., and Alexander, J. O. D. (1967). British fournal of Dermatology, 76, 509 .

Fry, L., Kier, P., McMinn, R. M. H., Cowan, J. D., and Hoffbrand, A. V. (1967). Lancet, 2, 729 .

Fry, L., McMinn, R. M. H., Cowan, J. D., and Hoffbrand, A. V. (1969). Archives of Dermatology, 100, 129.

Hoffbrand, A. V., Newcombe, B. F. A., and Mollin, D. L. (1966). Journal of Clinical Pathology, 19, 17.

Holzback, R. T., Clark, R. E., Shipley, R. A., Kent, W. B., and Lindsay, G. E. (1962). Fournal of Laboratory and Clinical Medicine, 60, 902.

Larson, S. M., Tuell, H., Moores, K. D., and Nelp, W. B. (1970). Journal of Nuclear Medicine, 11, 341.

McCarthy, C. F., Fraser, I. D., Evans, K. T., and Read, A. E. (1966). Gut, 7,140

Marks, J., Shuster, S., and Watson, A. J. (1966). Lancet, 2, 1280.

Marsh, G. W., Lewis, S. M., and Szur, L. (1966). British fournal of Haema-

tology, 12, 161 .
Marsh, G. W., and Stewart, J. S. (1970). British fournal of Haematology, $19,445$.

Martin, J. B., and Bell, H. E. (1965). Canadian Medical Association fournal, 92, 875.

Pettit, J. E., et al. (1971). British fournal of Haematology, 20, 575.

Seah, P. P., Fry, L., Hoffbrand, A. V., and Holborow, E. J. (1971a). Lancet,

Seah, P. P., Fry, L., Rossiter, M. A., Hoffbrand, A. V., and Holborow, E. J. (1971b). Lancet, 2, 681 . Waters, A. H., and Mollin, D. L. (1961). Journal of Clinical Pathology, 14,
335. 